\title{
Sustainable Drinking Water Security Strategic Plan : A Case Study of Juba South Sudan
}

\author{
Harrison H. Boying1, Fang Ping ${ }^{2 *}$, Mohamed Yateh ${ }^{1}$, Mulenga Collins ${ }^{1}$, \\ Emmanuel W. Gore1, Wonleh S. Slehkie ${ }^{1}$
}

${ }^{1}$ College of Environmental Science and Engineering, UNEP-Tongji Institute of Environment for Sustainable Development, Tongji University, 1239 Siping Road, Shanghai, 200092, People Republic China

\section{${ }^{2 *}$ Shanghai Institute of Pollution Control and Ecological Security; State Key Laboratory of Pollution Control and Resources Reuse; Key Laboratory of Yangtze River Water Environment, Ministry of Education, Tongji University, Siping Rd 1239, Shanghai, 200092, People Republic of China}

E-mail: harrisonhenryboying@gmail.com; yatmed01@yahoo.com; mulengabesa02@gmail.com; waniemmanuel22@gmail.com; slehkiecwonleh1986@gmail.com

$$
\text { corresponding author details: Fang Ping; fangping2000@tongji.edu.cn }
$$

\begin{abstract}
South Sudan is currently fronting significant difficulties to achieve the 2030 Sustainable Development Goals 6 (SDGs) framed in 2015, concentrating on water as a path to sustainable development. The country capital city Juba is one of the drinking water insecure towns in the world due to a long civil war that destroyed basic infrastructures, encourage urbanization and rural urban immigration. This paper aimed to investigate drinking water quota per capita per day in other countries, suggest a drinking water budget per capita per day to Juba, estimate optimum capacity for drinking water treatment plant to the city, and recommend a suitable drinking water distribution system. Literature review methods under meta-analysis were conducted to assess the drinking water budget per capita per day for cities in the world and to investigate advantages and disadvantages of some drinking water distribution systems. Mathematical models were used to estimate the capacity of the drinking water treatment plant required in the city. The study concluded that amount of water needed for the city is $36 \times 10^{3} \mathrm{~m}^{3}$. It should be $35 \times 10^{3} \mathrm{~m}^{3}$ for the western side and $12 \times 10^{2} \mathrm{~m}^{3}$ for the eastern side of the city. It also found that a looped drinking water distribution system is the best option for the city. The study suggested construction of a new drinking water treatment plant to secure drinking water security and improve the drinking water distribution network.
\end{abstract}

Keywords: drinking water security; drinking water budget; sedimentation tank; drinking water distribution system

\section{INTRODUCTION}

Drinking water security relates to the accessibility of a sufficient quantity and quality of water for human health, livelihoods, habitats, and production, as well as a reasonable level of water-related risks to humans and ecosystem [1,2]. Factors such as physical scarcity due to lack of rainfall, desertification, inequality of geographical water distribution, and economic scarcity affect water availability [3]. Drinking water conservation always has been a priority of modern culture to reduce its destructive potential while growing its development capacity. It is also a big issue for most of the world's poor economic nations. The goal of drinking water provision is at the center of the fight for sustainable development, prosperity, and poverty reduction for those countries that have not yet accomplished it.

Water security often necessitates investments in water facilities and institutions. Countries with a scarcity of freshwater supplies will almost need more infrastructure and notable institutions, with the development of both of these being much more difficult when the waters are transboundary [1].

Water demand management is the adaptation and execution of a policy by a water institution to control water demand and use it to achieve economic growth, social development, and social equity $[4,5]$. On the other hand, water demand is the amount of water requested by consumers to satisfy their needs $[6,7]$. Water demand management is any socially beneficial activity that decreases average or peak water withdrawals or usage from surface or groundwater while maintaining or improving water quality [8]. Domestic water demand categorized into two: in-house and out-of-house use. Garden watering, swimming pools, public standpipes for public service, fountains are outdoors, and other in-house needs are included, including water for drinking, cooking, sanitation, house cleaning, laundry, and car washing. 
The liter per capita per day (L/cap/day) is a popular measurement of urban water demand.[9]. The private sector has involved in the management and funding of urban water supply schemes in various ways around the world [10-12]. These have ranged from service contracts for remote control of publicly owned and funded networks (as in France) to joint public-private operation and ownership through joint ventures (as in Colombia) to full privatization (such as in Great Britain). The corporatization of government-owned utility management has also increased [13].

The importance of enhancing the provision of clean water supply and sanitation services to the world's low-income countries has been recognized internationally through the Millennium Development Goals [14].

Urbanization, population growth, and climate change have increased the pressure on cities to develop their water management and supply arrangements. Jurisdictions worldwide have used various institutional frameworks, regulatory systems, and supply planning methods to manage urban water supply. Owing to the monopolistic and critical existence of the water supply market, governments always take the lead; for example, in South Africa, the legislation mandates that all households receive 200 liters of water per day for free $[15,16]$. The quality of raw water, the sedimentation tank, drinking water treatment technologies, and distribution infrastructure were all part of the urban water supply scheme [16].

On July 9, 2011, South Sudan declared independence from Sudan, ending a five-decade civil war that had destroyed the lives, livelihoods, and access to basic needs, including clean water. The country is currently fronting significant difficulties in achieving the 2030 Sustainable Development Goals 6 (SDGs) framed in 2015, concentrating on the water as a path to sustainable development to tackle poverty, hunger, gender inequity, etc. $[17,18]$.

The Ministry of Water Resources and Irrigation of South Sudan (MWRI) drafted a water policy, which ministers and the legislature authorized in November 2007. Water security has always been a priority for the South Sudanese government. Drinking water accessibility and quality have remained a significant challenge for the government in Juba [1]. The water policy aims to promote social-economic growth and development in South Sudan by promoting productive, reasonable, sustainable development and adequate water and hygiene facilities. On the other hand, it sets out the government's vision for the water sector and defines the fundamental philosophies that will direct the subdivision's growth throughout its recovery and expansion.
It describes general terms, including governance, rights, criteria, approach, institutional structure, and position separation [19].

Control of water supplies, sanitation, hygiene, and rural and urban water supply are among the priority areas listed in the strategic framework for future action. The structure requires subsector action plans and subsector investment plans. Activities and agendas to conserve water, mitigate runoff, and increase groundwater recharge are absent from this approach, crucial in areas where rainfall is minimal and highly unpredictable [20]. South Sudan's water management system did not represent the precise distribution of water supplies inside the nation's various developmental projects [21]

The population of Juba city increased dramatically after the independence of the country, which encourages the return of refugees, urbanization, and internal immigration.

The 21 years of the civil war not destroyed human resources alone but physical infrastructure. The existing water treatment plant with a design capacity of 5,200 m3 /d was not functioning properly before May 2009, and its working capacity was very limited. Water distribution network mainly composed of aged asbestos pipes causes high leakage. The water that is not treated adequately in the water treatment plant is supplying only to a fraction of government offices and households. Therefore, this situation encourages people to depend on unprotected wells, raw Water from River and streams, and getting more difficult to access water as drinking water truck is the popular water distribution system. The investigation concluded that two among three people in the country do not have access to safe and potable water supply services [18]. This paper investigates the drinking water budget per capita in developed and other African countries. It suggests a specific vacuum of sedimentation tank and drinking water distribution system to Juba, South Sudan

\section{MATERIALS AND METHODS}

\section{About the Study Area}

Juba is the capital city of the Republic of South Sudan and Central Equatoria State. Its located at a longitude of $4^{\circ} .51^{\prime}$ $.0^{\prime \prime}$ North and a latitude of $31^{\circ} .37^{\prime}$. 0" East. With an elevation of 457 meters above sea level. Greater Juba, including the surrounding rural lands, encompasses roughly 23 kilometers in diameter with a population density of $1,577,902$ with a growth rate of 1.92 . The population is believed to be $1,520,027$ on the western and 37,875 people on the eastern side [22]. Juba has a spectacular landscape with rugged topography, high grounds, and plains with a gentle slope to the North [23]

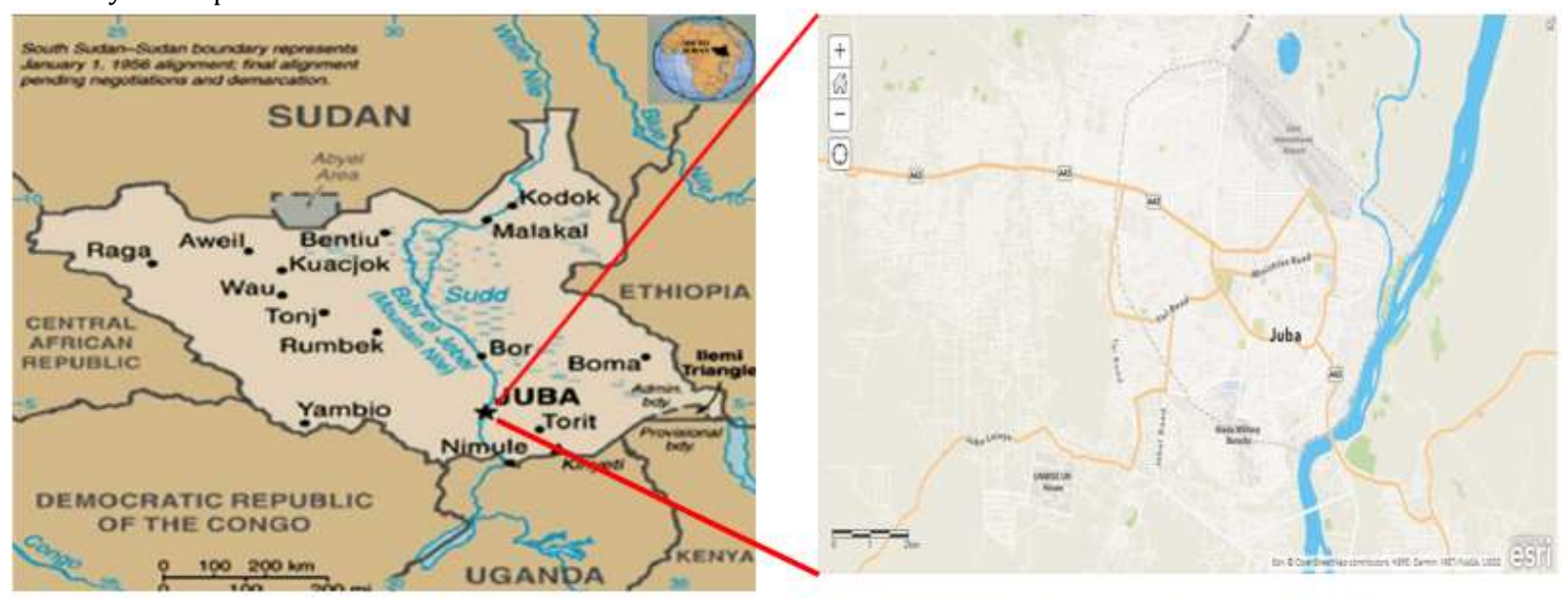

FIGURE 1: The map of Juba 


\section{- Source of Drinking Water in Juba}

The source of drinking water in Juba is the River Nile, whereby $72.5 \%$ of the citizen depend, $15 \%$ depending on the borehole, and 12.5 obtaining their water from sallow wells [24]. $57.5 \%$ of the water supply in Juba is through water tanks, $42.5 \%$ receiving their drinking water by containers, jerrycan vendors, and private wells through human beings [25].

\section{- Capacity of the Current Drinking Water Treatment Plant in Juba}

Before completing the existing treatment plant's rehabilitation in May 2009, Juba people couldn't obtain safe and clean water. After the completion, it has estimated that the water budget per person in Juba was around 30 Litres per person per day. However, the existing water treatment plant with a design capacity of 5,200 m3 /day, which equivalent to 3.1 liters per person per day and was not functioning properly [26].
Methodology

- Investigation of the Drinking Global Water budget and Water Distribution System

The systematic search and review processes applied following the Preferred Reporting Items for Systematic Reviews and Meta-Analyses (PRISMA) Statement criteria proposed by Frederick [27, 28]. Bibliometric sources included Web of Science, Science Direct, and Google Scholar are used to abstract articles and book chapters published from 2015 to 2020 by using keywords; water budget per capita per day in USA city New York, China city Shanghai, Canadian city Toronto, Botswana city of Gaborone, Zambian city Lusaka, Mauritius city Port Louis, Ethiopian city of Addis Ababa, and South Sudan city of Juba. Advantages and disadvantages of drinking water distribution system of Branched, Looped, and truck are considered based on affordability and environment of the area. Based on chronological order, 45 references were cited (FIGURE 2).

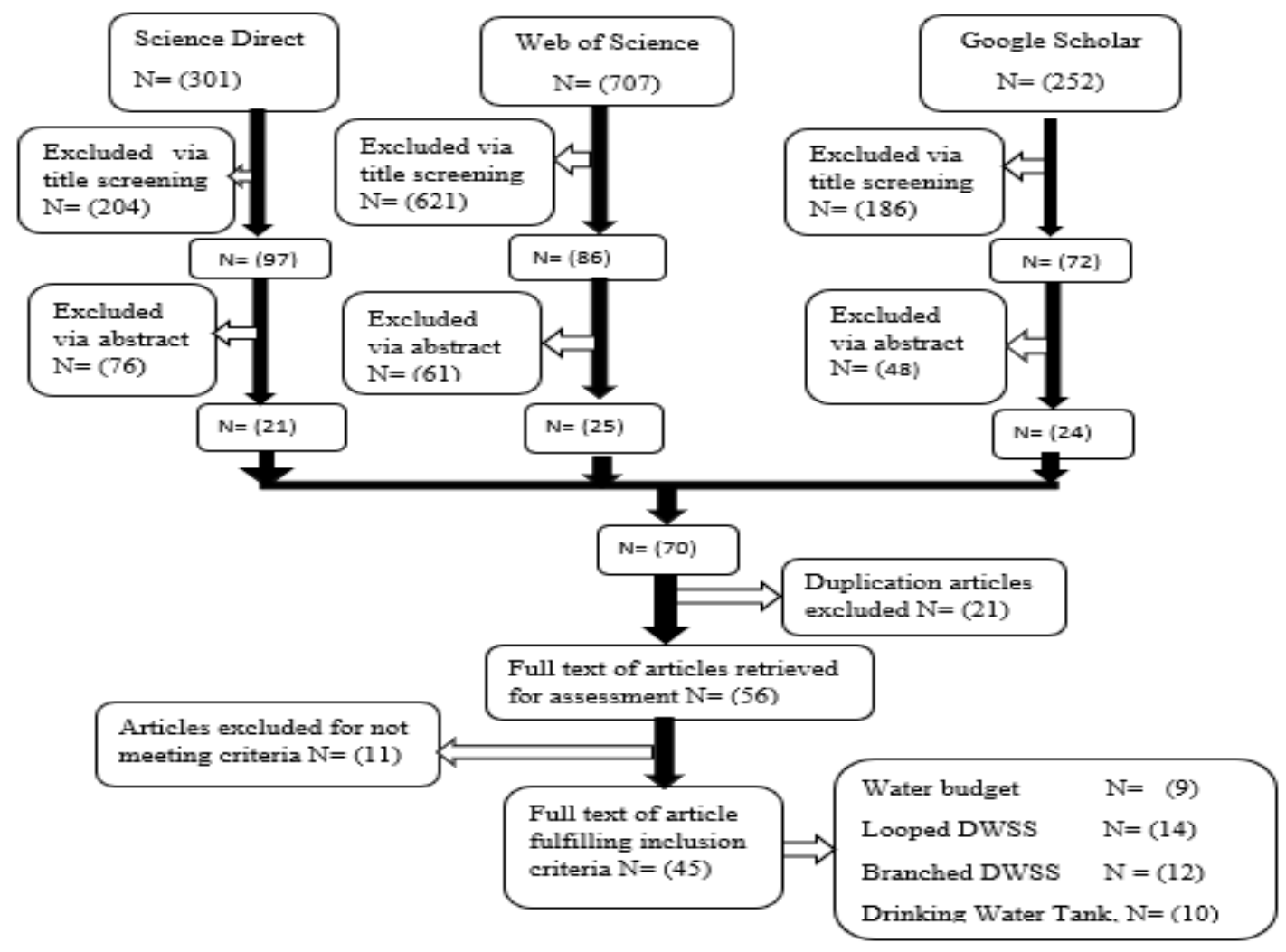

FIGURE 2: The chronological process for PRISMA

\section{- Water Demand Per Day Calculation}

The quantity of water demand is equal to the amount of water suggested per capita multiplied by its population density. The average water quota per capita per day of China megacities was applied [29].

$$
\mathrm{WD}=\sum_{k=0}^{n}(\mathrm{Pop}) \mathrm{r}
$$

WD=Water Demand, Pop= Population density, "r" is the water budget per person per day (L)

\section{- Water Required Per Day}

The quantity of water required is the amount of water demand by the population and the expected water lost through leaking and seepage. The proposed amount to be lost is assumed to be 0.1 percent

$$
W R=\sum_{k=0}^{n}(\mathrm{Pop}) \mathrm{r} * \mathrm{e}
$$

WR is the total water required, Pop refers to population density, and "e" is the expected water lost during distribution.

\section{- Quantity of water to be Treated During the Detention Period}

With the suggested water detention period of two hours in the treatment plant, the amount of water to be treated calculated used the formula below.

$$
Q=\frac{(W D)}{24} X E
$$

Q is water required to be treated within two hours; WD is the water demand within a day, and $\mathrm{E}$ is the detention period, 24 is the hours per day.

\section{- Length of the Tank}

$$
\mathrm{L}=\mathrm{V} * \mathrm{~T}
$$

Whereby $\mathrm{L}=$ The length of the sedimentation tank $\mathrm{V}=$ Flow velocity $\mathrm{T}=$ Detention period 


\section{- Calculation of Cross-Section Area}

$\mathrm{A}=\frac{W R}{L}$

A is the cross-section area, WR is the capacity of the Tank, and $\mathrm{L}$ is the length of the Sedimentation tank.

\section{- Width of the Sedimentation Ta nk Calculation}

$\mathrm{B}=\frac{A}{H}$

Whereby B is the Tank's width, A refers to the crosssection area, $\mathrm{H}$ is the Tank's depth. With the assumption of 4.5 meters' depth

\section{- The Dimension of the Tank}

The size of the thank $d=L^{*} B * H$

Whereby d reflects the Tank's dimension or vacuum, $\mathrm{L}$ is the length, B is the Tank's width, and H refers to tank dep

\section{RESULTS AND DISCUSSIONS}

- The Quota of Water in the USA Cities

The amount of water used at home is directly proportional to the number of people living in that home. Utah's population increased by $33 \%$ between 2000 and 2015, and the average daily water consumption per person is 151200 gallons. Idaho has grown by $27 \%$ from 2000 to 2015 , with average daily water consumption of 151-200 gallons per individual. Citizens in other fast-expanding states, such as Texas and Florida, witness a similar connection between increasing population and rising average water consumption per person, usually about 76-100 gallons per day[30]. However, global climate change factors can directly affect the relationship with water at home[31].

\section{- The Quota of Water in China Cities}

Water consumption increasing sharply as industrialization and urbanization intensify. China's total water consumption in 2018 was 601.55 billion $\mathrm{m} 3$, a rise of 69.6 billion $\mathrm{m} 3$ from 2003. Every sector's water consumption has increased over the last 15 years. The most significant upgrades were ecological water usage and domestic water consumption, with percentages of 151.8 percent and $35.8 \%$, respectively [32]. In China, the average daily water consumption per capita is between 260 and 419 liters [33]
- The Quota of Water in Canadian Cities

The average Canadian uses 329 liters per day. The average person in Quebec uses 400 liters of water per day. The average Montrealer uses 225 liters of water every day, according to the City of Montréal. It is challenging to pin down an actual number because Montreal does not meter residential water, unlike other large Canadian cities. Some boroughs and demerged towns do meter water; however, many areas do not.

Because of leakage and pipeline breaks, managers have to handle much more drinking water than is needed. Water treatment plants produce $1104 \mathrm{~L}$ of water per person per day, more than twice the quantity of water produced per capita in Toronto and Vancouver. This total represents residential, commercial, manufacturing, institutional, and public use, as well as the $20-40 \%$ of our drinkable water that is lost each year due to leaks and 500 pipe bursts[34].

\section{- The Quota of Water in Africa Countries}

Despite increased over access to improved water facilities in Sub-Saharan Africa in 2017, piped water access steadily declined. Piped water access is limited in some parts of Sub-Saharan Africa, where population growth may be outpacing infrastructure development. The majority of interventions have focused on increasing access to better wells.

The majority of African countries' drinking water utilities do not reach the entire city [35]. It recognized that the new water supply network could only provide $36 \mathrm{~L} / \mathrm{p} / \mathrm{d}$ of Water on average in Kenya. However, even for low-income households, the system must have $60 \mathrm{~L} / \mathrm{p} / \mathrm{d}$, according to national standards[36]. While the drinking water budget per capita in Addis Ababa city of Ethiopia was 155 liter per capita, for Port Louis Maruti use was 200 Liters per capita, Lusaka city of Zambia is 225 Liter per person per day [37].

\section{- The water quota in Juba}

Most of the families in Juba rely on wells and water trucks. Since most wells are highly salinity, and some of the wells are polluted, drinking water truck delivery systems become common. However, the water budget per capita is assumed to be 30 liters per day [38].

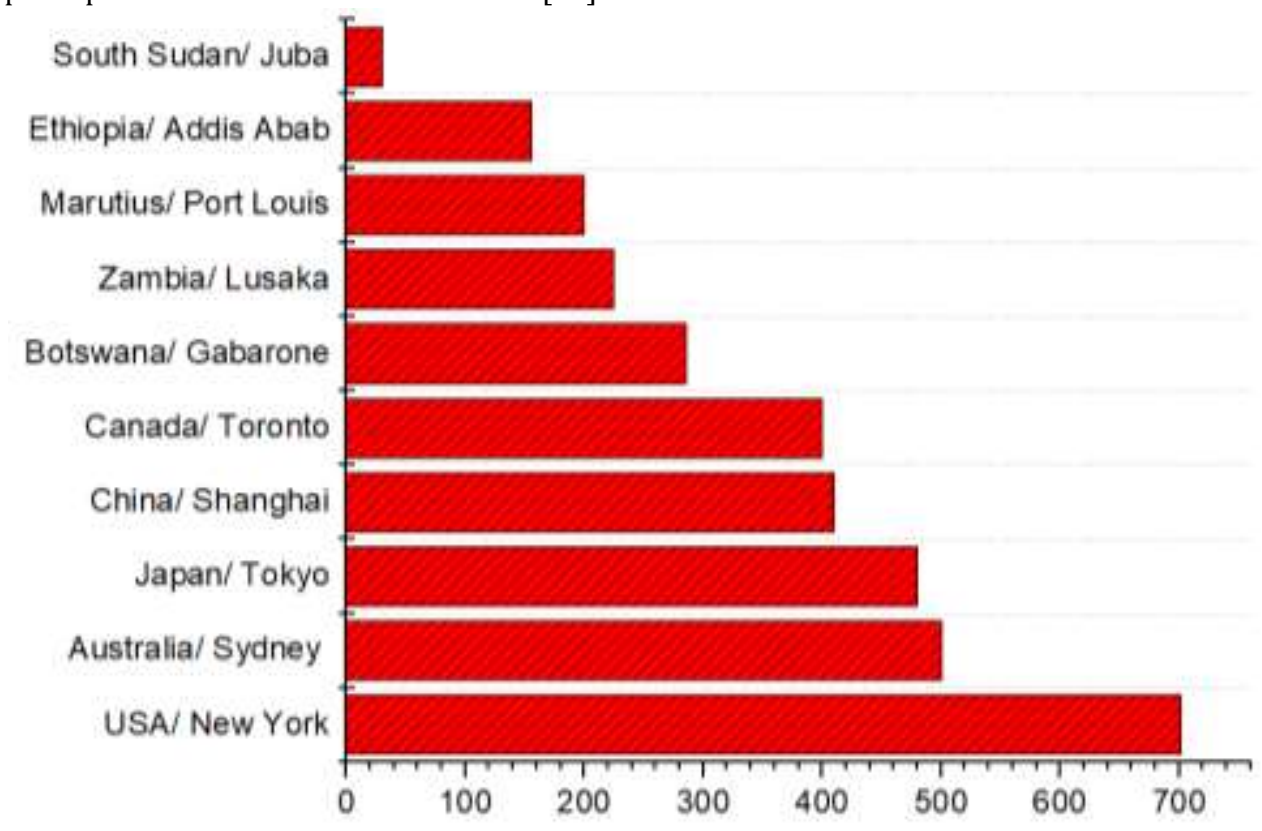

FIGURE 3: Water Demand per capita per day for different cities in the world 


\section{- Drinking Water Demand in Juba}

Water demand was calculated by obtaining data on Juba population density from literature; the drinking water budget per person per day is designed from the average water required per person in China's Megacities, 275 liters per person day [33]. Equation (1) was used to calculate total water demand to the area. The result shows that for Juba to be drinking water secured, $418 \times 10^{6}$ liters of water need to be supplied per day.

\section{- Water Required in Juba}

The quantity of water required is calculated by multiplication the expected amount of water needed per person per day and the predicted water loss through leaking and seepage. The projected amount to be lost design to be 1.1 percent of the water demand. Equation (2) above indicated that the total water required per day was designed to be $436 \times 10^{6}$ Liters. Because the river divided the city into two, western and eastern sides, the amount of water suggested to the west was $422 \times 10^{6}$ liters, and for the east side would be $145 \times 10^{5}$ Liter.

\section{- Water to Be treated Within Detention Period}

The water quantity to be treated within two hours of detention was calculated using equation (3) above to assess the amount of water treated in the sedimentation tank within two hours. Therefore, the water needs to be treated within two hours of detention period for people of Juba was calculated to be $36 \times 10^{3} \mathrm{~m}^{3}$. Because the city is along both sides of the river, water required in the plant within two hours on the western side is $35 \times 10^{3} \mathrm{~m}^{3}$ and for the eastern side is $12 \times 10^{2} \mathrm{~m}^{3}$.

\section{- Length of Sedimentation Tank Calculation}

The length of the sedimentation tank calculated using equation (4) above; the result shows that the length of sedimentation tank needed should be 216 miters based on the calculation below;

\section{$L=0.6 \times 6 \times 60=216$ Miters}

- Calculation of the Cross-Section Area of the Sedimentation Tank for Both Sides

Cross-sectional areas of the sedimentation tank calculated to determine the width of the drinking water treatment plant tank. Equation (5) was apply for the study; The result indicated that the sedimentation tank's cross-sectional area on the western side assesses to be $162881 \mathrm{~m}^{2}$. The amount of eastern waterside was estimated to be was calculated to be $5631 \mathrm{~m}^{2}$

\section{- The Width Sedimentation Tank Calculation}

The width of the expected sedimentation tank calculated using formula (6) above. It was calculated by dividing the predicted Tank's cross-section area by the Tank's proposed depth, which design to be 4.5 miters. Therefore, the width of the sedimentation tank at the western side found to be 36196 meters, and the width of the sedimentation tank needed at the eastern side found to be 1251 miters

\section{- The Proposed Dimension for Drinking Water Treatment Plant}

The equation (7) above shows that the sedimentation tank's size needed to fulfill Juba people with enough water at both western and eastern is; $35 \times 10^{6} \mathrm{~m}^{2}$. Western side designs $12 \times 10^{5} \mathrm{~m}^{2}$ at the east side.

\section{- Drinking Water Supply Technologies}

The two basic configurations primarily used for water distribution systems are the branch and grid/loop [39, 40]. In some cases, people used drinking water trucks [41].

\section{Branching Pattern with Dead End}

A topologically branched drinking water configuration network is a series of pipes connected so that all of its elements can only emerge from one end. As a result, the flow in Dead End Branched is one-way. The system is mainly used in rural areas [42]. The typical branched network has one supply point and many ends[43]. As a result, when recurrent stagnations occur during noconsumption cycles, the branched system's flow is usually sporadic. Because water will travel long-distance at a lower velocity in this method, disinfectant residuals vanish, disinfection byproducts form excessively, and biofilm forms [44]. For small communities, branched networks are sufficient, as long as the investment costs are reasonable. However, the system's key drawbacks remain low system reliability [45]. Large sections of the network may be without water, especially when there is maintenance upstream [34]. Stagnation of the Water at the system's ends ('dead' ends) causes sediment accumulation, which can cause taste and odor issues-water supply fluctuations due to periodic water intensity reductions due to heat loss [46].

The benefits of a branched drinking water configuration network, on the other hand, are simplicity and ease of installation in small cities due to the small number of pipes needed and ease to measure. Because of its simplicity, the device is cost-effective since it needs few materials to cover a large area [40]. The region receiving water from a pipe under repair will be without water until the work was finished, which is one of the limitations of a branched drinking water delivery system[47]. In this system, there are several dead ends where water does not flow and stays stagnant [48].

The stagnation of the dead-end could result in sediment accumulation and microbial contamination [49]. During maintenance, a lot of water will be lost. And it is heard that the chlorine level at the pipe's dead ends should be kept constant. The amount of water intended to stop fires is limited mainly by using this system [50]. As more areas of the water supply system are added, the pressure at the end of the line may become very low [51]. It requires multiple suppliers [52].

\section{Looped Drinking Water Distribution System}

Looped drinking water delivery systems consist of nodes that may receive water from multiple sources[50]. The looped drinking water configuration network was created to address branched systems' weaknesses. A loop system can be built from a branched system by linking the ends later or as a looped series. This structure has the advantage of allowing water to flow in more than one direction and preventing long-term stagnation[53]. Since water in the supply system will flow in several directions, stagnation is less likely than a branching pattern. If a pipe is repaired or breaks down, the area connected to that pipe will continue to receive Water because Water will flow in from the other side[54]. With the minimal head loss, the water hits all stages. Drinking water for the entire city can be obtained from a single source. During fires, much of the water supply can be quickly redirected and concentrated for firefighting by controlling the cut-off valves [43, 55]. A pressure increase caused by a limited supply of water in pumping systems [56]. Pressure variations would be less affected by fluctuations in water demand. However, looped systems are much more complex than serial or branched structures [54].

The system's flow pattern is dictated not only by its design but also by its operation. As a result, the position of critical pressures will change over time. When there are many sources of supply to calculate or assess materials required 
will become very difficult [40]. Looped systems are more expensive, both in terms of initial investment and ongoing operating expenses [40, 57]. It is a primarily suitable solution for potable water distribution in urban or industrial areas requiring a high system and stability [58]. The cost of pipe laying is expensive due to the relatively more length of pipes [59]. Many valves and pipes are needed, making the system too expensive, and their calculation is more complicated [54].

\section{Water Truck Distribution System}

Drinking water trucks are used effectively in firefighting in rural areas, and the list develops cities where there are no fire hydrants or other ready water sources [60]. Bulk water supply companies use trucks to transport water to swimming pools and other landscape water bodies. It's helpful in drought-stricken areas or on residential properties that rely on untreated drinking water. Water trucks will easily carry in potable water without draining or damaging the water pump, rather than waiting days for hoses to fill a pool [39].
Water trucks assure water supply in isolated areas. The drinking water truck conceded the faster water supply that can help emergencies such as Natural disasters, such as floods, earthquakes, and hurricanes. This technology represents a quick solution for providing water for areas with no other potable water sources; It provides job opportunities and income for tanker trucks' distributors and owners [61, 62]. However, this system's disadvantages are water source is not always verified, and the system is dependent on the trucks [63]. Trucks breakdown could harm the system if there are just a few trucks[64]. They deliver very often low-quality Water $[49,65,66]$. The transportation costs are primarily high and will vary with fuel, governance, accessible road for the trucks, and management policies. The water quality can't be easily monitored and can easily pollute while filling the tanks and the distribution. The trucks would contribute to city environmental deterioration through carbon dioxide emission, traffic issues and requires constant maintenance [67]

\begin{tabular}{|c|c|c|}
\hline Technology & Advantages & Disadvantages \\
\hline Looped & -Water flow in more the one direction & -High cost of pipe laying \\
\hline \multirow[t]{5}{*}{ system } & -No stagnation & -More number of valves required \\
\hline & -No water cut-off during repairing & -Complication in pipe calculation \\
\hline & -Minimum head loss & \\
\hline & -Single source is enough to supply & \\
\hline & -Water is enough for fire fighting & \\
\hline Branched & -Simple method of water distribution. & -No water downstream when repairing \\
\hline \multirow[t]{7}{*}{ system } & -Pipes calculations are easy. & -Large number of dead ends \\
\hline & -It's cheaper compared to loop & -Sediments accumulate \\
\hline & -Less number of valves required. & -Bacterial growth due to dead end \\
\hline & & -It isn't easy to maintain a chlorine residual \\
\hline & & -Limited Water for firefighting \\
\hline & & -Reduction of pressure by distant \\
\hline & & -It requires multiple suppler \\
\hline Drinking- & -Assure water in isolated areas & -Water source is not always verified \\
\hline \multirow[t]{4}{*}{ Water Truck } & -Can be used for emergency & -Depending on the accessibility of trucks, fuel, \\
\hline & -Source of job & and management \\
\hline & & -Often, low-quality water \\
\hline & & -High chance of recontamination \\
\hline
\end{tabular}

\section{CONCLUSION AND RECOMMENDATIONS}

Literature review methods under meta-analysis were applied to assess the drinking water budget of the United States, China, Canada, Botswana, Zambia, Marutiuse, and Ethiopia; and to investigate suitable drinking water distribution systems, out of 1243 articles found only 45 papers cited. The average water budget per capita per day of China's megacities was suggested to be used in Juba. Mathematical equations applied to project the size of the sedimentation tank suitable for the area. treatment plants needed to secure drinking water to both sides of the Juba was found to be $36 \times 10^{3} \mathrm{~m}^{3}$ well for the western side would be $35 \times 10^{3} \mathrm{~m}^{3}$, and $12 \times 10^{2} \mathrm{~m}^{3}$ on the eastern side. The study concluded that a looped drinking water distribution system has more advantages to the branched and drinking water truck system. As it allows water to flow in more than one direction, no stagnation of water, rarely water cut-off during repairing, the head loss is shallow and single source is enough to supply, 
always water is enough for firefighting, the pressure is almost high everywhere. Although it showed a high cost of materials and complication in pipe calculation, it is convenient compared to a branched system and water truck. The study recommended that the new drinking water treatment plant be based in upstream areas of Juba to reduce the cost of treatment by reducing the chance of River Nile water contamination from urban runoff and facilitating the distribution system. The study also recommends the government install a looped drinking water distribution system in Juba city to reduce its risk of drinking water insecurity.

\section{ACKNOWLEDGMENT}

The author acknowledges the support offered by Tongji University (Shanghai), in particular, the Institute of Environmental Sciences and Sustainable Development (IESD) and my supervisor, Prof Fang Ping, for being supportive during proceeding with this article.

\section{REFERENCES}

[1] C. W. Sadoff and D. Grey, "Sink or Swim? Water security for growth and development," Water Policy, vol. 9, no. 6, pp. 545-571, 2007.

[2] D. K. K. Elishiba Njambi Kimani, "Gender and poverty reduction: A Kenyan context," Educational Research and Reviews, vol. 5, 2010.

[3] Ú. Oswald Spring, "- On Health and Water Security," pp. - 392, 2020.

[4] G. De Winnaar and G. Jewitt, "Ecohydrological implications of runoff harvesting in the headwaters of the Thukela River basin, South Africa," Physics and Chemistry of the Earth, Parts $A / B / C$, vol. 35, no. 13-14, pp. 634-642, 2010.

[5] D. Jiru, "Indiscriminate devegetation under improper farming system: a root cause for surface and underground water and food crisis in Ethiopia," Ecohydrology \& Hydrobiology, vol. 10, no. 2-4, pp. 201-209, 2010.

[6] S. R. Majid Zaremehrjardya, Monireh Faramarzia, "Assessment of the cascade of uncertainty in future snow depth projections across watersheds of mountainous, foothill, and plain areas in northern latitudes," Journal of Hydrology, vol. 8, no. 11, pp. 125-735, 2020.

[7] D. M. Lumbroso, Sakamoto, D., Johnstone, W., Tagg, A. and Lence, B.L., "THE DEVELOPMENT OF A LIFE SAFETY MODEL TO ESTIMATE THE RISK POSED TO PEOPLE BY DAM FAILURES AND FLOODS," Journal of the British Dam Society, vol. 7, pp. 122-189, 2017.

[8] M. Zaremehrjardy, S. Razavi, and M. Faramarzi, "Assessment of the cascade of uncertainty in future snow depth projections across watersheds of mountainous, foothill, and plain areas in northern latitudes," Journal of Hydrology, p. 125735, 2020.

[9] V. D. Welday Berhe, "Water Supply Coverage and Water Loss in Distribution Systems the case of AddisAbaba,"https://webapps.itc.utwente.nl/libr arywww/papers_2015/msc/upla/desalegn.pdf, vol. 1, pp. 212-314, 2015.
[10] D. Di, Z. Wu, H. Wang, and S. Huang, "Optimal water distribution system based on water rights transaction with administrative management, marketization, and quantification of sediment transport value: A case study of the Yellow River Basin, China," Sci Total Environ, vol. 722, p. 137801, Jun 202020.

[11] V. G. Gude and P. J. Muire, "Preparing for outbreaks - Implications for resilient water utility operations and services," Sustainable Cities and Society, vol. 64, p. 102558, 2021.

[12] L. Li, "Private sector participation and performance of county water utilities in China," China Economic Review, vol. 52, pp. 30-53, 2018.

[13] L. Yao and B. Sui, "Heterogeneous preferences for shale water management: Evidence from a choice experiment in Fuling shale gas field, southwest China," Energy Policy, vol. 147, p. 111831, 2020.

[14] U. Nation, "The Millennium Development Goals Report 2008,"

https://www.un.org/millenniumgoals/2008highl evel/pdf/newsroom/mdg\%20reports/MDG_Repor t_2008_ENGLISH.pdf, pp. 1-51, 2008.

[15] K. Abeysuriya, C. Mitchell, and S. White, "Can corporate social responsibility resolve the sanitation question in developing Asian countries?," Ecological Economics, vol. 62, no. 1, pp. 174-183, 2007.

[16] M. Cosier and D. Shen, "Urban Water Management in China," International Journal of Water Resources Development, vol. 25, no. 2, pp. 249-268, 2009.

[17] K. M. K. Kut, A. Sarswat, J. Bundschuh, and D. Mohan, "Water as key to the sustainable development goals of South Sudan - A water quality assessment of Eastern Equatoria State," Groundwater for Sustainable Development, vol. 8, pp. 255-270, 2019.

[18] K. M. K. Kut, A. Sarswat, J. Bundschuh, and D. J. G. f. S. D. Mohan, "Water as key to the sustainable development goals of South Sudan-a water quality assessment of eastern Equatoria state," vol. 8, pp. 255-270, 2019.

[19] A. Schriewer et al., "Human and Animal Fecal Contamination of Community Water Sources, Stored Drinking Water and Hands in Rural India Measured with Validated Microbial Source Tracking Assays," Am J Trop Med Hyg, vol. 93, no. 3, pp. 509-516, Sep 2015.

[20] N. F. a. W. Garvey, "The Rapid Water Sector Needs Assessment and a Way Forward," World Bank Research Observer, vol. 79923, p. 127, 2013.

[21] D. Requejo-Castro, R. Gine-Garriga, and A. PerezFoguet, "Data-driven Bayesian network modelling to explore the relationships between SDG 6 and the 2030 Agenda," Sci Total Environ, vol. 710, p. 136014, Mar 252020.

[22] S. S. g. report, "Juba, South Sudan Geographic Information," https://www.latlong.net/place/juba-southsudan-12954.html, p. 1, 2015 
[23] S. M. Adak, "The geology of Juba and the surrounding area, Central Equatoria Final Report,"

https://www.academia.edu/22921696/The_Geol ogy_of... 2015.

[24] Q. S. Martin Kajokare Karija, Yata Samuel Lukaw, "The Impact of Poor Municipal Solid Waste Management Practices and Sanitation Status on Water Quality and Public Health in Cities of the Least Developed Countries: the Case of Juba, South Sudan," International Journal of Applied Science and Technology, vol. 3 p. 4, 2013.

[25] J. Leju Celestino Ladu, A. L. Athiba, S. Tombe Venusto Lako, and M. Lomoro Alfred, "Investigation on the Impact of Water Pollution on Human Health in Juba County, Republic of South Sudan," Journal of Environment Pollution and Human Health, vol. 6, no. 3, pp. 89-95, 2018.

[26] M. o. P. infrustructure, "JUBA URBAN WATER SUPPLY AND CAPACITY DEVELOPMENT STUDY IN THE SOUTHERN SUDAN," p. 6, 2015.

[27] F. A. Armah, R. Quansah, and I. Luginaah, "A Systematic Review of Heavy Metals of Anthropogenic Origin in Environmental Media and Biota in the Context of Gold Mining in Ghana," Int Sch Res Notices, vol. 2014, p. 252148, 2014.

[28] C. Teodosiu, A.-F. Gilca, G. Barjoveanu, and S. Fiore, "Emerging pollutants removal through advanced drinking water treatment: A review on processes and environmental performances assessment," Journal of Cleaner Production, vol. 197, pp. 1210-1221, 2018.

[29] G. M. Fair, Geyer, J. C. and Okun, D. A. , "Separation of Suspended Solids by Sedimentation Processes," Social and Civil Engineering, vol. 12, no. 9, pp. 1124-1128., 2018.

[30]H. Lv et al., "Water resource synergy management in response to climate change in China: From the perspective of urban metabolism," 2020.

[31] E. P. A. (EPA), "Average Household Water Usage in the United

States,"https://www.aquasana.com/info/educati on/average-water-usage-in-the-united-states, 2020.

[32] Y. Yang, W. He, F. Chen, and L. Wang, "Water footprint assessment of silk apparel in China," Journal of Cleaner Production, vol. 260, p. 121050, 2020.

[33] M. Zhang, M. Zhang, H. Zhao, and M. P. van Dijk, "Managing water demand by contract: a survey of conservation outsourcing in China," Utilities Policy, vol. 67, p. 101128, 2020.

[34] M. University, "How much are we using?," https://www.mcgill.ca/waterislife/waterathome /how-much-are-we-using, 2020.

[35] M. Molinos-Senante, S. Munoz, and A. Chamorro, "Assessing the quality of service for drinking water supplies in rural settings: A synthetic index approach," J Environ Manage, vol. 247, pp. 613623, Oct 12019.
[36] M. O. E. Kenya, "THE DEVELOPMENT OF THE NATIONAL WATER MASTER PLAN 2030," Jica, vol. 1, pp. 1-46, 2013.

[37] WASH, "Global Water Facts - Safe Water Access Matters,"

https://www.worldometers.info/water/) and (https://www.statista.com/statistics/263156/wa ter... 2021.

[38] T. Kuroyanagi, "JUBA URBAN WATER SUPPLY AND CAPACITY DEVELOPMENT STUDY IN THE SOUTHERN SUDAN," https://openjicareport.jica.go.jp/pdf/11961844_ 01.pdf, pp. 09-105, 2009.

[39] R. A. M. B. Yesus E. M. Vieiraa*, Luiz A. S. Lopesa, Orivalde S. Silva Júniora, Marcílio M. Batista Júniorb, "A procedure to support the distribution of drinking water for victims of drought: the case of the Brazilian semi-arid region," Transportation Research Procedia, vol. 47, pp. 331-339, 2019.

[40]A. Gurung and R. Martínez-Espiñeira, "Determinants of the water rate structure choice by Canadian municipalities," Utilities Policy, vol. 58, pp. 89-101, 2019.

[41] I. R. Abubakar, "Factors influencing household access to drinking water in Nigeria," Utilities Policy, vol. 58, pp. 40-51, 2019.

[42] A. A. Abokifa, P. Biswas, B. R. Hodges, and L. Sela, "WUDESIM: a toolkit for simulating water quality in the dead-end branches of drinking water distribution networks," Urban Water Journal, vol. 17, no. 1, pp. 54-64, 2020.

[43] G. Pelletier, S. Rochette, and M. Rodriguez, "Impacts of the ageing and rehabilitation of water pipes on residence times at the residential neighborhood scale," Urban Water Journal, vol. 14, no. 9, pp. 940-946, 20172017.

[44] A. A. Abokifa, Y. J. Yang, C. S. Lo, and P. Biswas. , "Water Quality Modeling in the Dead End Sections of Drinking Water Distribution Networks.," Water Research, vol. 89, no. 9, pp. 107-117. , 2016.

[45] Z. Xu et al., "Flat flexible thin milli-electrode array for real-time in situ water quality monitoring in distribution systems," Environmental ScienceWater Research \& Technology, vol. 3, no. 5, pp. 865-874, Sep 12017.

[46] S. R. Poleneni and E. C. Inniss, "Array of prediction tools for understanding extent of wall effects on DBP formation in drinking water distribution systems," Journal of Water Supply Research and Technology-Aqua, vol. 68, no. 6, pp. 390-398, Sep 12019.

[47] A. Menapace, D. Avesani, M. Righetti, A. Bellin, and G. Pisaturo. , "Uniformly Distributed Demand EPANET Extension.," Water Resources Management, vol. 32, no. 6, pp. 2165-2180., 2018.

[48] E. Abraham, M. Blokker, and I. Stoianov, "Decreasing the Discoloration Risk of Drinking Water Distribution Systems through Optimized Topological Changes and Optimal Flow Velocity Control," Journal of Water Resources Planning and Management, vol. 144, no. 2, Feb 2018, Art. no. 04017093 . 
[49] A. Farenhorst et al., "Bacteria in drinking water sources of a First Nation reserve in Canada," Sci Total Environ, vol. 575, pp. 813-819, Jan 12017.

[50] D. J. Williams, C. J. Parrett, M. R. Schock, C. Muhlen, P. Donnelly, and D. A. Lytle, "Design and Testing of USEPA'S Flint Pipe Rig for Corrosion Control Evaluation," Journal American Water Works Association, vol. 110, no. 10, pp. E16-E37, Oct 2018.

[51] K. Kosaka et al., "National survey of utilization of continuous water quality monitors in water supply systems in Japan," Water Science and Technology-Water Supply, vol. 19, no. 5, pp. 13471353, Aug 2019.

[52] G. Venkatesh, A. Chan, and H. Brattebø, "Understanding the water-energy-carbon nexus in urban water utilities: Comparison of four city case studies and the relevant influencing factors," Energy, vol. 75, pp. 153-166, 2014.

[53] P. Jamwal and M. S. M. Kumar, "Effect of flow velocity on chlorine decay in water distribution network: a pilot loop study," Current Science, vol. 111, no. 8, pp. 1349-1354, Oct 252016.

[54] M. Klien and D. Michaud, "Water utility consolidation: Are economies of scale realized?," Utilities Policy, vol. 61, p. 100972, 2019.

[55] C. Agudelo-Vera, M. Blokker, J. Vreeburg, H. Vogelaar, S. Hillegers, and J. P. van der Hoek, "Testing the Robustness of Two Water Distribution System Layouts under Changing Drinking Water Demand," Journal of Water Resources Planning and Management, vol. 142, no. 8, Aug 2016, Art. no. 05016003.

[56] H. Wong, Y. R. Filion, and V. Speight, "A Neighbourhood-Level Analysis of the Impact of Common Urban Forms on Energy Use in Drinking Water Distribution Systems," Water Resources Management, vol. 34, no. 9, pp. 2641-2655, Jul 2020.

[57] T. Guo, J. D. Englehardt, and H. J. Fallon, Jr., "Modeling the Economic Feasibility of LargeScale Net-Zero Water Management: A Case Study," Water Environment Research, vol. 88, no. 9, pp. 811-823, Sep 12016.

[58] J. Bienvenido Martinez, "Quantifying the economy of water supply looped networks," Journal of Hydraulic Engineering-Asce, vol. 133, no. 1, pp. 88-97, Jan 2007.
[59] J. Bienvenido Martinez, "Quantifying the economy of flow distribution in water supply looped networks," Journal of Hydroinformatics, vol. 13, no. 4, pp. 687-698, 20112011.

[60] C. H. Jones, J. Meyer, P. K. Cornejo, W. Hogrewe, C. J. Seidel, and S. M. Cook, "A new framework for small drinking water plant sustainability support and decision-making," Sci Total Environ, vol. 695, p. 133899, Dec 102019.

[61] M. J. Gunnarsdottir et al., "Status of risk-based approach and national framework for safe drinking water in small water supplies of the Nordic water sector," Int J Hyg Environ Health, vol. 230, p. 113627, Sep 182020.

[62] D. W. Mapunda, S. S. Chen, and C. Yu, "The role of informal small-scale water supply system in resolving drinking water shortages in peri-urban Dar Es Salaam, Tanzania," Applied Geography, vol. 92, pp. 112-122, 2018.

[63] A. V. Kulinkina et al., "Rural Ghanaian households are more likely to use alternative unimproved water sources when water from boreholes has undesirable organoleptic characteristics," Int J Hyg Environ Health, vol. 227, p. 113514, Jun 2020.

[64] M. M. Hasan and K. Alam, "Inequality in access to improved drinking water sources and childhood diarrhoea in low- and middle-income countries," Int J Hyg Environ Health, vol. 226, p. 113493, May 2020.

[65] D. Holcomb, L. Palli, K. Setty, and S. Uprety, "Water and health seminar and special issue highlight ideas that will change the field," Int J Hyg Environ Health, vol. 226, p. 113529, May 2020.

[66] L. Rocha-Melogno et al., "Rapid drinking water safety estimation in cities: Piloting a globally scalable method in Cochabamba, Bolivia," Sci Total Environ, vol. 654, pp. 1132-1145, Mar 1 2019.

[67] M. Beeftink, B. Hofs, O. Kramer, I. Odegard, and A. van der Wal, "Carbon footprint of drinking water softening as determined by life cycle assessment," Journal of Cleaner Production, vol. 278, p. 123925, 2021. 